\title{
State InNOVATION IN HEAlth CARE: CONGRESS' BROAD SPENDING POWER UNDER A NATIONAL HEALTH CARE SYSTEM WILL STIFLE STATE LABORATORIES OF DEMOCRACY
}

\author{
A government that is big enough to give you all you want is \\ big enough to take it all away. - Barry M. Goldwater
}

Tammy Murray*

\section{INTRODUCTION}

The Supreme Court's recent decisions in United States v. Lopez ${ }^{1}$ and United States $v$. Morrison ${ }^{2}$ articulate a vision of federalism which severely limits Congress' regulatory authority under the Commerce Clause in favor of state or local control of traditional areas of state concern. The Court's decisions coincide with ballot initiatives that show the states still desire to maintain control over many aspects of healthcare; medicinal marijuana, physician-assisted suicide, and embryonic stem cell research are a few prominent examples. While some of these issues face challenges under federal law, Congress' authority to regulate intrastate activities based on a tenuous connection to commerce is no longer a foregone conclusion.

Still, the spending power of the federal government is nearly limitless, allowing it to influence or control state government regulation of health care. A national health care system will stifle the states' ability to experiment with health care issues and reform. Ultimately, the states' ability to function as laboratories of democracy in search of solutions or in experimental areas that lack a national consensus will be lost if a national health care plan is implemented without imposing limitations on the broad congressional spending power.

* J.D. Candidate, 2006, Indiana University School of Law - Indianapolis; M.B.A., 2001, B.S., 1994, University of Missouri-Columbia. Recipient of the Indiana Bar Association Distinguished Writing Award 2005. I would like to thank J. Brad Kallmyer and Lakshmi Reddy for their guidance in writing this note. In addition, I would like to thank my husband, Robert, and my children, Adrian, Chelsea and Todd for their love, patience and understanding as I pursue my legal education. Lastly, I would like to thank my fellow classmate and friend, Alexis Sumner, for helping me maintain my sanity during law school.

1. United States v. Lopez, 514 U.S. 549, 567-68 (1995) (invalidating a firearms possession Act that neither regulated a commercial activity nor contained a requirement that the possession be connected in any way to interstate commerce, exceeding the authority of the Commerce Clause).

2. United States v. Morrison, 529 U.S. 598, 626-27(2000) (striking down a federal civil remedy for the victims of gender-motivated violence because Congress lacked constitutional authority). 
Health care reform is a hot topic for political platforms, perhaps second only to the War on Terrorism in 2004. ${ }^{3}$ Escalating costs in health care and increasing numbers of uninsured persons in the United States are strong incentives for health care reform, and the debate over how to address the health care crisis has led to a political stalemate. Therefore, the status quo has been the least risky political option for the decision makers in Washington. Both President Clinton and 2004 presidential candidate John Kerry proposed creating a national health care plan offering universal health care coverage. President Clinton's plan, however, did not garner support in Congress and Kerry failed to sway the American people.

Reluctance of voters to allow the federal government to expand its role in health care regulation can be justified on many grounds. The federal government may impose uniformity at the cost of overutilization of a scarce resource, raising the tax burden. People fear rationing at the cost of human lives. Citizens of states that have or are seeking to develop successful health programs fear federal preemption of their efforts and disregard for their values. Ultimately, there is apprehension that federal uniformity will be achieved not only with a high economic cost, but also the cost of state and personal autonomy that may never be recovered.

Over the last twenty years, the idea of federalism and the state's ability to better serve its citizens' interests has been revived after a dormant phase following the New Deal. ${ }^{4}$ Policymakers are reassessing the idea that national problems require control and resolution by the federal government. ${ }^{5}$ In the absence of adequate federal government solutions, several states have emerged as experimental laboratories for important health care issues. ${ }^{6} \mathrm{~A}$ national health care system is certainly not ripe for implementation. It would impede the important laboratories of democracy function of the states, which have historically been granted the power to regulate health care. ${ }^{7}$ Further, realistic limitations on Congress' spending power are needed to avoid coercion to comply with a federal monopoly on health care at the expense of state innovation.

This note explores the legislature's current regulation of health care under the Medicare Program and how a national health care plan would affect the states' ability to serve as laboratories of democracy or to experiment with their own health care solutions. Part II demonstrates how state experimenta-

3. Kaiser Family Foundation, Health Care and the 2004 Elections (Sept. 27, 2004), available at $\mathrm{http}: / / \mathrm{www} . \mathrm{kff} .0 \mathrm{~g} / \mathrm{kaiserpolls} / 7167 . \mathrm{cfm}$.

4. Steven G. Calabresi, Federalism and the Rehnquist Court: A Normative Defense, 574 ANNALS 24, 25 (2001).

5. Jeffrey Modisett, Symposium, Discovering the Impact of the "New Federalism" on State Policy Makers: A State Attorney General's Perspective, 32 IND. L. REV. 141, 141 (1998).

6. See discussion infra Part II.B.

7. Kevin Outterson, Health Care, Technology and Federalism, 103 W. VA.L. REV.503, 504 (2001). 
tion has led to national solutions, how state and federal governments learn from each other's failed programs, and how state autonomy allows flexibility to meet the needs of a state's electorate. Part III explains the importance of federalism and the Supreme Court's recent decisions limiting the Commerce Clause and upholding the Tenth and Eleventh Amendments. Part IV reviews the current state of health care in the United States, the need for health care reform, and the political pressure for a national health care system. Part V traces the federal government's regulation of health care under the Medicare Program and its use of the congressional spending power to induce cooperation with federal policy that entails more than providing health insurance to the elderly. Part VI examines the federal government's ability to regulate participants in a national health care plan that would have the effect of coercing federal compliance to participate in the United States Health Care System. Under the current spending power limitations, this coercion may be unconstitutional. If it is not a constitutional violation, states will lose the ability to serve as laboratories of democracy or to regulate an area that has traditionally been reserved as a state power under the constitution.

\section{STATES AS LABORATORIES OF DEMOCRACY}

\section{A. Brandeis' Dissent}

Political judgments about particular health care reform requirements are products of personal experience, political beliefs, and local economic and social conditions. These factors change substantially from one region of the United States to another. To be acceptable and tailored to individual citizen's needs, health care reform and experimentation must take account of the real differences between New York and California, Indiana and Arizona. It is specifically in this context that federalism can play a crucial role in making real medical reform and state experimentation feasible, successful, and acceptable to most citizens.

The argument for state experimentation was given its most famous expressions in opinions by Justices Holmes and Brandeis. Brandeis' articulate argument in New State Ice Co. v. Liebmann ${ }^{8}$ has become part of the federalist phrase: "It is one of the happy incidents of the federal system that a single courageous State may, if its citizens choose, serve as a laboratory; and try novel social and economic experiments without risk to the rest of the country." A decade earlier, Holmes set the stage for this argument by praising federalism for allowing states to be "insulated chambers" in which legislative experimentation could be undertaken with little danger to other

8. New State Ice Co. v. Liebmann, 285 U.S. 262 (1932).

9. Id. at 311 (Brandeis, J., dissenting). 
states or the nation. ${ }^{10}$ In essence, the laboratory of democracy theory supports the idea that states should be able to test their own solutions to problems observed in their constituencies and diverge from national solutions that prove ineffective. ${ }^{11}$

Perhaps the Court's recent decisions in favor of constitutionally supported state authority will be a return to Justice Brandeis' vision of fifty independent laboratories yielding their best results for the nation. ${ }^{12}$ This proposition is true especially in areas of diverse solutions, where states may implement legislation that likely never will obtain national consensus.

\section{B. Current State Experimentation in Health Care}

Several states in the absence of national solutions have been innovators in health care litigation and financing reform as well as morally controversial areas that lack a national consensus. State experimentation, both successes and failures, is the key to Justices Holmes and Brandeis' theory of state laboratories.

\section{Medicinal Marijuana}

The voters of California, through the state's initiative process, passed the Compassionate Use Act of $1996^{13}$ to ensure that seriously ill Californians have the "right to obtain and use marijuana for medical purposes,"14 that "patients and their primary caregivers who obtain and use marijuana for medical purposes . . . are not subject to criminal prosecution,"15 and "to encourage the federal and state governments to implement a plan to provide for the safe and affordable distribution of marijuana to all patients in medical need of marijuana."16 California's law is in direct conflict with federal laws, which classify marijuana as a Schedule I controlled substance, making the use and distribution illegal. ${ }^{17}$

Had voter mandates legalizing medicinal marijuana been enacted in only a few states, federal enforcement strategies such as suspending a health care

10. Truax v. Corrigan, 257 U.S. 312, 344 (1921) (Holmes, J., dissenting).

11. Alistair E. Newbern, Comment, Good Cop, Bad Cop: Federal Prosecution of StateLegalized Medical Marijuana Use After United States v. Lopez, 88 CAL. L. REV. 1575, 1626 (2000).

12. Id. at 1627 .

13. CAL. Health \& SAFETy CoDE $\S 11362.5$ (West 2005).

14. $I d . \S 11362.5(\mathrm{~b})(1)(\mathrm{A})$.

15. Id. $\S 11362.5(\mathrm{~b})(1)(\mathrm{B})$.

16. Id. $\S 11362.5(\mathrm{~b})(1)(\mathrm{C})$.

17. 21 U.S.C. $\$ 812$ (2005) Schedule I drugs have "(B) ... no currently accepted medical use in treatment ..." and " $(C)[t]$ here is a lack of accepted safety for use of the drug ... under medical supervision." Id. $\S 812$ (b)(1)(B) and (C) (2005). 
provider's license and prohibiting participation in Medicare or Medicaid programs might well have suppressed state initiatives. ${ }^{18}$ Since the midnineties, however, eleven states and two localities ${ }^{19}$ have passed medical marijuana laws similar to California's and have in some way lessened or eliminated state criminal penalties for possessing medicinal marijuana. ${ }^{20}$ The United States Court of Appeals for the Ninth Circuit has ruled that states are free to adopt medicinal marijuana laws so long as it is not sold, transported across state lines or used for nonmedicinal purposes. ${ }^{21}$ This ruling only applies to the western states in the Ninth Circuit's jurisdiction and has been appealed to the Supreme Court. ${ }^{22}$ On November 29, 2004, the United States Supreme Court heard oral arguments in Ashcroft v. Raich ${ }^{23}$ and reversed the Ninth Circuit and held that wholly intrastate, non-commercial cultivation, possession, and use of marijuana in accordance with state law does not place a person beyond the reach of the federal government under the Controlled Substance Act.

\section{Physician-Assisted Suicide}

Voters of Oregon legalized physician-assisted suicide ("PAS") in $1994 .^{24}$ The Oregon Death with Dignity Act allows terminally ill Oregon residents to obtain prescriptions for self-administered, lethal medications from their physicians and pharmacists. ${ }^{25}$ The Act permits PAS, but specifically prohibits euthanasia or the direct administration of a medication by a physician to end a person's life. ${ }^{26}$

On November 6, 2001, however, United States Attorney General John Ashcroft issued a directive which reinterpreted the Controlled Substances Act

18. See discussion infra Part VI.

19. Angie Wagner, How the West Was Won Over: With Montana Vote, Nearly ThreeFourths of the West Now Covered by Medical Marijuana Laws, Assoc. Press, Nov. 11, 2004. After the 2004 elections, most states supporting Medicinal marijuana are in the West: Montana, Alaska, California, Colorado, Hawaii, Nevada, Oregon, Washington and Arizona. States outside the West include Maine and Vermont and local measures have passed in Columbia, Missouri and Ann Arbor, Michigan. Id.

20. Newbern, supra note 11, at 1577 .

21. Raich v. Ashcroft, 352 F.3d 1222, 1234-35 (2003) (holding that the Controlled Substance Act was an unconstitutional exercise of congressional commerce power when applied to citizens who use marijuana that has not traveled interstate and was never intended for interstate or foreign commerce).

22. Id.

23. Ashcroft v. Raich 03-1454, U. S. Supreme Court oral arguments (Nov. 29, 2004), available at $\mathrm{http}: / / \mathrm{www}$. supremecourtus.gov/oral_arguments/argument_transcripts/03-1454.pdf. Gonzales v. Raich, 545 U.S. 1, 16 (2005).

24. Oregon Death with Dignity Act, OR. REV. STAT. § 127.800-127.995 (2003).

25. Id. $\S 127.805(2003)$.

26. Id. $\S 127.880$ (2003). See also Lindsay R. Kandra, Comment, Questioning the Foundation of Attorney General Ashcroft's Attempt to Invalidate Oregon's Death with Dignity $A c t, 81$ OR. L. REV. 505, 509 (2002). 
as to invalidate Oregon's Death with Dignity Act. ${ }^{27}$ The directive stated that prescriptions issued for the purpose of assisting suicide were not a "legitimate medical purpose" and the use of a controlled substance to assist in suicide is per se illegitimate. ${ }^{28}$ "This was the first time in history that the Controlled Substances Act was used to preempt state law."29 Ashcroft's directive threatens physicians with suspension of their medical licenses and possible criminal prosecution, even when they proceed in accordance with the Act. ${ }^{30}$ This invalidation of the Oregon Act through the federal prosecution of physicians is a clear interference with traditional state government powers: to regulate public health and medical licensing. ${ }^{31}$

Moral decisions such as the legality of PAS are profoundly personal and should be made as close to the voters as practical. ${ }^{32}$ Voters have greater influence and more opportunity to participate in policy decisions at the local or state level than at the national level and therefore, the state's electorate should determine for themselves whether PAS is appropriate policy. ${ }^{33}$ Ashcroft's directive was held invalid at the district court ${ }^{34}$ and appellate court levels based on federalism principles. ${ }^{35}$ As a rationale supporting state sovereignty, the Supreme Court stated "[t]hroughout the Nation, Americans are engaged in an earnest and profound debate about the morality, legality,

27. Dispensing of Controlled Substances to Assist Suicide, 66 FED. REg. 56,607 (Nov. 9, 2001) (codified at 21 C.F.R. pt. 1306).

28. Id. See Memorandum from John Ashcroft, Attorney General to Asa Hutchinson, Drug Enforcement Administrator (Nov. 6, 2001)(on file with Indiana Health Law Review)(stating assisting suicide is not a "legitimate medical purpose" within the meaning of 21 C.F.R. $\$ 1306.04$ (2001), and that prescribing, dispensing, or administering federally controlled substances to assist suicide violates the CSA).

29. Kandra, supra note 26, at 505-506.

30. Dispensing of Controlled Substances to Assist Suicide, 66 Fed. Reg. 56,607 (Nov. 9, 2001) (codified at 21 C.F.R. pt. 1306).

31. Kandra, supra note 26, at 505-506.

32. See discussion infra Part III.A.

33. Christin A. Batt, Comment: The Pain Relief Promotion Act of 1999 and PhysicianAssisted Suicide: A Call for Congressional Self-Restraint, 38 SAN DIEGO L. REV. 297, 325-27 (2001).

34. Oregon v. Ashcroft, 192 F. Supp. 2d 1077, 1092-93 (D. Or. 2002).

35. Oregon v. Ashcroft, 368 F.3d 1118, 1131 (9th Cir. 2004). "The principle that state governments bear the primary responsibility for evaluating physician assisted suicide follows from our concept of federalism, which requires that state lawmakers, not the federal government, are 'the primary regulators of professional [medical] conduct."' (quoting Conant $\mathrm{v}$. Walters, 309 F.3d 629, 639 (9th Cir. 2002)); see also Washington v. Glucksberg, 521 U.S. 702, 737 (1997)(O'Connor, J., concurring). The Supreme Court has made the constitutional principle clear: "Obviously, direct control of medical practice in the states is beyond the power of the federal government." Linder v. United States, 268 U.S. 5 (citation omitted) (1925); see also Barsky v. Bd. of Regents, 347 U.S. 442 (citation omitted) (1954) ("It is elemental that a state has broad power to establish and enforce standards of conduct within its borders relative to the health of everyone there. It is a vital part of a state's police power."). The Attorney General "may not ... regulate [the doctor-patient] relationship to advance federal policy." Conant, 309 F.3d at 647 (Kozinski, J., concurring). Id. at 1124. 
and practicality of physician-assisted suicide" and "[o]ur holding permits this debate to continue, as it should in a democratic society." ${ }^{36}$ This debate may not end with national consensus; however, state autonomy to experiment with and permit PAS should not be stifled by the federal government.

\section{Embryonic Stem Cell Research}

The national debate over the use of embryos for stem cell research has resulted in private entities conducting research without government guidelines or regulation. In 2004, Californians voted with a fifty-nine percent majority to borrow $\$ 3$ billion to fund stem cell research over the next ten years. ${ }^{37}$ California is targeting research areas such as new lines of embryonic stem cells ("ESC") where federal money is not available. ${ }^{38}$ "Funding from the California Stem Cell Research and Cures Initiative, which may total as much as $\$ 350$ million per year, could dwarf other expenditures on ESC." ${ }^{\prime 39}$ The National Institutes of Health spent less than \$25 million on this type research in 2003 , although it expended more than $\$ 380$ million on adult stem cell research. ${ }^{40}$ The pledge of new money might entice stem cell researchers to California and the strong public support of the research "certainly helps the field overall." ${ }^{41}$ Further, the competition may stimulate increased funding by other states. For example, New Jersey allocated $\$ 6.5$ million for a new stem cell institute in May $2004 .^{42}$

Embryonic stem cell research is a very controversial area in which a national consensus to spend federal tax dollars may never be achieved. California's initiative to experiment in this area is precisely defined by "a single courageous State may, if its citizens choose, serve as a laboratory; and try novel social and economic experiments without risk to the rest of the country." ${ }^{33}$ Learning from the benefits and detriments of this experiment in California may lead to a national solution to the debate.

\section{Partial-Birth Abortion}

Another area of controversy is the legality and morality of a specific abortion procedure. President Bush signed the Partial-Birth Abortion Ban

36. Washington v. Glucksberg, 521 U.S. 702, 735 (1997).

37. Don Monroe, California Bets Big on Stem Cell Research (Nov. 4, 2004), at $\mathrm{http}: / / \mathrm{www}$. sciam.com/article.cfm?articleID=000C585B-3A47-1189-BA4783414B7F0000.

38. Id.

39. Id.

40. Id.

41. $I d$. (citing the co-director for the Harvard Stem Cell Institute).

42. Id.

43. New State Ice Co., 285 U.S. at 311 (Brandeis, J., dissenting). 
Act $^{44}$ ("PBABA") into law in 2003; it is a federal ban on partial-birth abortions except when necessary to save the life of the mother. ${ }^{45}$ Specifically, $\S 1531$ (a) of PBABA provides: "[a]ny physician who, in or affecting interstate or foreign commerce, knowingly performs a partial-birth abortion and thereby kills a human fetus shall be fined under this title or imprisoned not more than 2 years, or both." 46 Many states had implemented bans on partial-birth abortion prior to the enactment of the federal ban. ${ }^{47}$

A Nebraska statute, however, was found unconstitutional under a substantive Due Process challenge because the law lacked any exception "for the preservation of the . . . health of the mother" and it "imposes an undue burden on a woman's ability" to choose the method of abortion, thereby burdening the right to choose abortion itself. ${ }^{48}$

Federal judges have predicted that the federal ban is likely to be unconstitutional because it contradicts the Supreme Court ruling that struck down the Nebraska statute. ${ }^{49}$ In the Court's words, although in a different context, "the field of health care [is] a subject of traditional state regulation ..." 50 The federal government may regulate economic activity within health care, but the noneconomic aspects of medicine may be off limits because of the tradition of state regulation in this domain and the lack of any real national interest. ${ }^{51}$ Subject only to the Fourteenth Amendment, the regulation of abortions has been the exclusive territory of the states before and after Roe $v$. Wade. ${ }^{52}$ Congress uses its spending power to impose limits on the federal

44. Partial-Birth Abortion Ban Act, 18 U.S.C. $\$ 1531$ (2005).

The term 'partial-birth abortion' means an abortion in which the person performing the abortion (A) deliberately and intentionally vaginally delivers a living fetus until, in the case of a head-first presentation, the entire fetal head is outside the body of the mother, or, in the case of a breech presentation, any part of the fetal trunk past the navel is outside the body of the mother, for the purpose of performing an overt act that the person knows will kill the partially delivered living fetus; and (B) performs the overt act, other than completion of delivery, that kills the partially delivered living fetus ...

Id. § 1531(b)(1) (2005).

45. Allan Ides, The Partial-Birth Abortion Act of 2003 and the Commerce Clause, 20 CONST. COMMENT. 441, 441 (2003-2004).

46. Partial-Birth Abortion Ban Act, 18 U.S.C. §1531(a) (2005).

47. National Right to Life Committee Inc., States that Passed Legislation Outlawing Partial-Birth Abortion (Mar. 25, 2004), available at http://www.atr.org/special/maps/data/ Abortion_legislation.pdf.

48. Stenberg v. Carhart, 530 U.S. 914, 929-30 (2000) (quoting Planned Parenthood of Southeastern Pa. v. Casey, 505 U.S. 833, 874, 879 (1992)).

49. Howard Mintz, Federal Judges in New York, San Francisco Halt Abortion Ban, SEATTLE TIMES, Nov. 7, 2003, available at http://seattletimes.nwsource.com/html/ nationworld/2001785268_abort07.html.

50. Pegram v. Herdrich, 530 U.S. 211,237 (2000).

51. Ides, supra note 45 , at 454.

52. Id. 
funding of abortions, but the actual regulation of abortions remains a state freedom. ${ }^{53}$

Under Lopez and Morrison, the presumption of unconstitutionality established by the noneconomic nature of the activity is further strengthened by the traditional role of the states in regulating crime and health care, and by the weakness of the argument that partial-birth abortions substantially affect interstate commerce. ${ }^{54}$ Even if the Court finds the federal ban on partial-birth abortion unconstitutional under the Commerce Clause, a national health care plan will allow Congress to control providers by exercising its spending power. ${ }^{55}$

\section{Health Care Financing and Medical Malpractice Reform}

Laboratories of democracy are operating to meet states' economic concerns in providing for the health of their citizens. States have a large stake in health care reform; in 1999, twenty-seven percent of total state budgets were consumed by health care services. ${ }^{56}$ In the 1980 's when comprehensive health care reform dropped off the federal radar screen, states were left to develop solutions to their citizens' health care needs. ${ }^{57}$ In addition, federal spending decreased and existing programs were used by the federal government to force participation in programs by insuring new groups. ${ }^{58}$ These unfunded mandates and the federal government's increased state flexibility in offering Medicaid and Medicare waivers demanded greater state involvement in health care financing.

At the same time, the cost of care continues to increase and health care providers' reimbursement rates are decreasing; some providers are closing their practices to federal entitlement recipients such as Medicare patients. ${ }^{59}$ While this outcome is contrary to the intended goal of the Medicare program, the impact does not stop there because "[m]ost of the nation's private health insurance companies benchmark their fee schedules to the Medicare physician

53. Id.

54. Id. at 461-62.

55. See discussion infra Part VI.B.

56. FederalisM \& HEALTH POLICY 60 (John Holahan et al. eds., 2003).

57. Robert F. Rich \& William D. White, Symposium: Federalism and Health Care Policy, 1998 U. ILL. L. REV. 861, 874-75 (1998).

58. Id. (stating under Medicaid, states were offered the option of either covering new groups or pulling out of the program entirely).

59. William F. Jessee, Statement of the Medical Group Mgmt. Assoc. to the Practicing Physician's Advisory Group: 2004 Medicare Physician Fee Schedule (Feb. 10, 2003), available at http://www.cms.hhs.gov/faca/ppac/oral_mgma.pdf. Medicare physician reimbursement fees deceased in 2003 by $4.4 \%$. Id. 
fee schedule." ${ }^{\prime 60}$ Therefore, reimbursement rates decrease across the private market as well.

In the absence of federal solutions to the health care crisis and unfunded mandates to states by the federal government to retain participation in federal programs, states have become innovators in health care financing. Several states have undertaken comprehensive health care financing reform in diverse ways. While they have had varying degrees of success and can provide examples for other state reform, many of the states that abandoned universal coverage cite federal roadblocks to reform as the cause.$^{61}$ Hawaii is perhaps the best known success story; it provides health care coverage for between ninety-five and ninety-eight percent of its adult population through an extraordinary combination of reform strategies. ${ }^{62}$ Other reform examples include Maryland's regulation of hospital rates, which is the most developed and successful in the country, and New York's rate of growth in hospital spending, which is among the lowest. ${ }^{63}$

The states' familiarity with local health care delivery requires that they be the innovators of health care reform across the nation. "States have implemented programs mandating employers to provide health insurance to their employees, rationing medical services to the poor, enlarging purchasing pools, expanding Medicaid to cover all uninsured residents at or below the federal poverty level, and providing improved benefits packages for children, among other reforms." ${ }^{.64}$ Successes in some states lay the foundation for further health care reform in other states. ${ }^{65}$

60. Id. Medicare has unfairly included prescription drugs as physician services to reduce reimbursement, while providing a different definition to limit ancillary services. Id.

61. See discussion infra Part II-C. See also Howard M. Leichter, State Governments and their Capacity for Health Care Reform in HEALTH POLICY, FEDERALISM, AND THE AMERICAN STATES 172 (Robert F. Rich \& William D. White eds., 1996).

62. Jerry L. Mashaw \& Theodore R. Marmor, Commentary, The Case for Federalism and Health Care Reform, 28 CONN. L. REv. 115, 124-25 (1995) (stating Hawaii uses play or pay, monopoly bargaining, voucher-type gap filling and a single-payer regulatory control).

63. Id.

64. Scott D. Litman, Note, Health Care for the Twenty-First Century: The Need for a Federal and State Partnership, 7 CORNELL J. L. \& PUB. POL'Y 871, 880 (1998).

65. Id. 
Also, states have been innovators in controlling medical costs associated with managed care ${ }^{66}$ malpractice litigation, ${ }^{67}$ and defensive medicine ${ }^{68}$ Some states have enacted legislation of medical malpractice caps and set up medical review panels and boards. ${ }^{69}$ A 2003 study examined state data from 1993 to 2002 and found that a cap on noneconomic damages and a ban on punitive damages enacted together reduced malpractice premiums by more than onethird. ${ }^{70}$ In addition, states without malpractice reform are facing decreased medical access and physician shortages. ${ }^{71}$ In 1975 , Indiana was one of the first states to enact comprehensive malpractice reforms. ${ }^{72}$ Indiana's reforms have gained national attention and several states have used these reforms as a model. ${ }^{73}$ California's medical malpractice reform also is successful and was

66. Centers for Medicare \& Medicaid Services, Health Care Industry Market Update: Managed Care (Mar. 24, 2003), available at http://www.cms.hhs.gov/reports/hcimu/ hcimu_03242003.pdf [hereinafter CMS-Update]. Two-thirds of commercially insured Americans were in PPO and POS plans, while one-fourth are in HMOs. Id.

67. Congressional Budget Office, Economic and Budget Issue Brief: Limiting Tort Liability for Medical Malpractice (Jan. 8, 2004), available at http://www.cbo.gov/ showdoc.cfm?index $=4968 \&$ sequence $=0$ [hereinafter CBO-Economic]. Malpractice costs amounted to an estimated $\$ 24$ billion in 2002, but that represents less than two percent of health care spending. $I d$.

68. George McGovern \& Alan Simpson, We're Reaping What We Sue, WALLST.J., April 17,2002 , at A20. A bipartisan group stated, "[1] egal fear drives [doctors] to prescribe medicines and order tests, even invasive procedures, that they feel are unnecessary. Reputable studies estimate that this 'defensive medicine' squanders $\$ 50$ billion a year ...." Id. See also Oversight Hearing on Health Care Litigation Reform: Does Limitless Litigation Restrict Access to Health Care? Hearings of Subcommittee on Commercial and Administrative Law, June 12, 2002, available at http://www.house.gov/judiciary/barr061202.htm. (hearing statement of Chairman Bob Barr). Practically untouched by the medical liability insurance crisis, Californians have enjoyed successful health care litigation reforms for over twenty-five years. Id. As a result, California's health care delivery is more accessible and cost-effective. Id.

69. CBO-Economic, supra note 67.

70. Id.

71. Texas Medical Association, Practice Management: Medical Liability and Lawsuit Abuse: A Profession in Crisis, available at http://www.texmed.org/liability/ProfessionIn Crisis.asp (last visited Jan. 16, 2005). "More than half of all Texas physicians . . . are considering early retirement due to [the] medical liability insurance crisis. About 40 percent say they are... [limiting] the patients they will accept. Nearly a third are reducing the types or kinds of services they provide[] and [a]lmost a fourth [are having] ... difficulties recruiting or retaining physicians in their communities." Id. See also Bob Keaveney, Physician-Friendly State, PHYSICIAN PRACTICE (July 2003), available at http://www.merritthawkins.com/ pdf/articles/Physician-friendly\%20states.pdf.

72. Eleanor Kinney, Symposium, Indiana's Medical Malpractice Reform Revisited: A Limited Constitutional Challenge, 31 IND. L. REV. 1043, 1046 (1998). Indiana Malpractice Act of Apr. 17, 1975, Pub. L. No. 146-1975, 1975 Ind. Acts 854 (codified as amended at IND. CoDE $\S \S 27-12-1-1$ to -18-2 (1993)). "The Act contains three major reforms: (1) a comprehensive cap on damages, (2) mandated medical review before trial, and (3) a state-run Patient Compensation Fund to pay large claims." Id.

73. Id. There are large discrepancies between state premiums. Letter from John C. Nelson, President American Medical Association, to Editor of the New York Times (Mar. 1, 2005), available at http://www,ama-assn.org/ama/pub/category/14764.html. "A typical ob-gyn 
the model for the federal Health Act of 2003, which passed the House and failed in the Senate by a margin of forty-nine to forty-eight. ${ }^{74}$ With further state testing, the likelihood of national comprehensive medical malpractice reform is encouraging.

State experimentation in the area of health care financing and medical malpractice reform allows states with similar problems to implement successful programs. It also helps to prevent avoidable failures because states may learn from the mistakes of other states. Further, the diverse needs and desires of a state's electorate can be considered and met without putting the entire nation in jeopardy with a uniform solution that may not be the best or even an adequate solution for any one state.

\section{Federal Road Blocks}

State innovation and implementation of health care reform has been hampered by Congress' unwillingness to restructure the Employee Retirement Income Security Act ("ERISA") ${ }^{75}$ preemption and offer Medicaid waivers. The major discrepancy between ERISA and health care reform stems from state laws that attempt to modify medical insurance plans and federal preemption which prevents significant reform. ${ }^{76}$ Obstacles do not develop from a state's inability to enact legislation, but rather from the inability to enforce the legislation against large employers. ${ }^{77}$

Companies that are protected by ERISA preemption are not required to comply with state insurance regulations and large companies that offer selfinsured medical plans to their employees have avoided paying state taxes on these benefits by using the preemption. ${ }^{78}$ This avoidance further cripples state governments' ability to finance health care reform. Congress' decision to support employment law over health care policy requires that state governments find creative ways to regulate health care while avoiding ERISA preemption. ${ }^{79}$ This difficulty has hindered important reforms in health care

in Los Angeles, where there is an effective cap on pain and suffering, pays $\$ 63,272$ for medical liability coverage. That same ob-gyn in Miami, where there's no effective cap in place, pays $\$ 277,241$ a year for the same coverage." Id.

74. William P. Gunnar, Is There an Acceptable Answer to Rising Medical Malpractice Premiums?, 13 ANN. HeALTH L. 465, 492 (2004).

75. Employee Retirement Income Security Act, 29 U.S.C. $§ 1108$ (2005).

76. Angelo A. Stio III, Note, State Government: The Laboratory for National Health Care Reform, 19 SETON HALl LEGIS. J. 322, 335 (1994).

77. Id. at 336.

78. Id. at 335 .

79. Litman, supra note 64 , at 884. 
and will continue to do so until either Congress or the Supreme Court grant states the ERISA exemption required for meaningful change. ${ }^{80}$

Medicaid waivers also play an important role in permitting states to experiment with different approaches to health care finance, delivery, and challenges of the particular needs of special groups. ${ }^{81}$ Similar to the problems in obtaining ERISA waivers, states have faced obstacles when they attempt to obtain Medicaid waivers from Congress. ${ }^{82}$ Since the Balanced Budget Act of 1997 , however, states have more flexibility concerning Medicaid and greater success has been produced by state experimentation with diverse constituents' needs. $^{83}$

\section{A National Solution Emerges}

\section{Experimentation without Putting the Nation at Risk}

Innovative state programs represent the core of Justice Brandeis' words when he wrote of the importance of maintaining the states as laboratories of democracy or the ability to test fifty techniques of dealing with a problem and adopt the most effective as a national solution. ${ }^{84}$ The nature of bureaucracy, coupled with the challenge of innovation, supports the notion of state tested solutions, "rather than reinventing the wheel at the federal level."85

State tobacco litigation provides the best example of state-initiated reform achieving national results. The attorney general of Mississippi filed the first state tobacco lawsuit in 1994 based solely on state-law theories. ${ }^{86}$ Soon after, other states filed similar suits. ${ }^{87}$ Early in the Mississippi litigation, the U.S. Department of Justice declined to join the tobacco litigation by becoming a party in existing cases or assisting the states in their suits. ${ }^{88}$

80. Stio, supra note 76, n.57. Members of Congress believe that employers would be subject to a web of state laws when operating in several states and political factions in each state would hamper employers' ability to efficiently manage benefits. Id.

81. Eleanor Kinney, Symposium, Current Issues in Insurance Law: Rule and Policy Making for the Medicaid Program: A Challenge to Federalism, 51 Оноо ST. L.J. 855, 873 (1990).

82. Fernando R. Laguarda, Note, Federalism Myth: States as Laboratories of Health Care Reform, 82 GEO. L.J. 159, 177-79 (1993).

83. CaRol S. Weissert \& William G. Weissert, Governing Health: THE Polttics of HEALTH POLICY 223-226 (2d ed. 2002).

84. See discussion supra Part II.A.

85. David L. Markell, States as Innovators: It's Time for a New Look to our "Laboratories of Democracy" in the Effort to Improve our Approach to Environmental Regulation, 58 ALB. L. REV. 347, 358 (1994).

86. Modisett, supra note 5 , at 152 .

87. Id. at n.87. Minnesota was the second state to file its suit in August 1994. See Minnesota v. Philip Morris, Inc, 551 N.W.2d 490 (Minn. 1995). Four years later, Nebraska became the forty-second jurisdiction to file suit. Modisett, supra note 5, at n.87.

88. Id. at 152 . 
Ultimately, several states proceeded alone and found themselves working jointly to produce a common result. ${ }^{89}$ Together, state attorney generals proposed settlement terms, conferred with public-health groups, advised governors and state legislators, and developed a plan to distribute settlement proceeds. $^{90}$

And what did the federal government do? A lien was placed on state proceeds by the Department of Health and Human Services before the money could grace states' coiffures ${ }^{91}$ on the theory that Medicaid claims constituted a part of the states' lawsuits. ${ }^{92}$

\section{Past Successes and the Importance of Failures}

Successful state innovation can be found across a spectrum of policy areas. In 1996, Congress turned over welfare regulation to the states on the laboratories of democracy theory. ${ }^{93}$ Several state experiments have been successful, especially the Wisconsin Works workfare program developed by Wisconsin Governor Tommy Thompson. ${ }^{94}$ Additional examples of successful state-initiated innovation include do-not-call lists for telemarketers, antitrust and child-labor laws, prescription-drug price limits, legal rights for homosexuals, background checks or waiting periods for gun buyers, limits on medical-malpractice claims, and deregulation of electricity. ${ }^{95}$ Also, women's

\section{Id.}

90. Joy Johnson Wilson, Federal Affairs Counsel Director, Health Committee National Conference of State Legislatures (Mar. 12, 1999), available at http://academic. udayton.edu/health/syllabi/tobacco/summary.htm. "On November 23, 1998 the Attorneys General and other representatives of 46 states, Puerto Rico, the Virgin Islands, American Samoa, the Northern Mariana Islands, Guam and the District of Columbia signed an agreement with the five largest tobacco manufacturers,... ending a four year legal battle between the states and the industry ... Four states (Florida, Minnesota, Mississippi and Texas) had previously settled with tobacco manufacturers for $\$ 40$ billion." Id.

91. Modisett, supra note 5, at 153.

92. Jeffery A. Modisett, Att'y Gen. of Ind., Univ. of California, San Fransisco, Prepared Testimony of Jeffrey A. Modisett Attorney General of Indiana before the House Committee on Commerce Subcommittee on Health and Environment (Dec. 8, 1997), available at $\mathrm{http}: / / \mathrm{www}$.library.ucsf.edu/tobacco/litigation/in/modtestimony.html?printfriendly=1\& (arguing the states expended resources to sue the tobacco industry and Medicaid claims constitute little if any part of states' lawsuits).

93. Newbern, supra note 11, at 1633.

94. Modisett, supra note 5, at 151-52.

95. Dennis Cauchon, Fed-up States Defy Washington, USA TodAY, Dec. 9, 2003, at 1A. Thirty-nine states had "do-not-call lists" for telemarketers before Congress created a federal list, and states had antitrust and child-labor laws before implementation by the federal government. Over two dozen states are trying to lower prescription-drug prices. Id. Maine penalizes pharmaceutical companies that refuse to sell drugs to uninsured people at the same discounted price as Medicaid pays. Variations on Maine's law have been enacted in Illinois, Hawaii, Montana and New Mexico. Id. Legal rights for homosexuals have made dramatic advances in the states; New Mexico was the fourteenth state to ban workplace discrimination against gays by public and private employers and the Massachusetts Supreme Judicial Court ruled that gay 
suffrage in Wyoming preceded national suffrages by thirty years. ${ }^{96}$ Putting theories to the test at the state and local government level is not only wise, it is crucial. "[S]trategies borne at these levels will have been battle-tested and are more likely to have been refined and made workable than those hatched far from the front lines." "[D] "[Damage resulting from innovations 'gone awry' is less significant, or at least localized, if the innovations occur at the state level rather than at the federal level . . ..,98 Health care issues are of vast importance and testing through state innovation should be welcomed by the federal government.

\section{E. States Learning from States}

Each state may exert its independent power as it desires, subject to the Supremacy Clause. ${ }^{99}$ States can choose different methods of regulating common goals, or they may regulate different objectives altogether because unique demographic, cultural, philosophical, or geographic influences will produce varying results. ${ }^{100}$ Over time, a state will be able to look to other states' approaches and results when implementing or assessing its own systems. ${ }^{101}$ In fact, Congress is allowing states to experiment with solutions to national problems. For instance, in the last few years, Congress has abolished federal welfare entitlement and permitted states to experiment with their own welfare systems. Also, the removal of the mandatory federal interstate speed limit allowed state legislatures to pass limits that they consider appropriate. $^{102}$ In the area of the environment, the Environmental Protection Agency has given the states more flexibility in enforcing environmental laws. ${ }^{103}$ Likewise, federal barriers should be removed to permit states to experiment and learn from other states' innovations in health care. ${ }^{104}$

couples have a right to marry. Id. Twenty-five states had background checks or waiting periods for gun buyers before the federal government required it in 1994. Id. Conservatives have enjoyed success too; among them are limits on medical-malpractice claims and deregulation of electricity. Id.

96. Fed. Energy Regulatory Comm'n v. Mississippi, 456 U.S. 742, 788 (1982)

(O'Connor, J., concurring).

97. Markell, supra note 85 , at 357.

98. Id. at 356-59.

99. Modisett, supra note 5, at 151.

100. Id.

101. Id.

102. Id. at 141.

103. Id. at 145.

104. Peggy L. Bartels \& Pris Baroniec, BadgerCare: A Case study of the Elusive New Federalism, HEALTH AFF. (Nov.-Dec. 1998), available at http://content.healthaffairs.org/cgi/ reprint/17/6/165.pdf. (raising federal government barrier concerns in seeking Medicare- Title XIX and CHIP- Title XXI waivers). BadgerCare would ensure access for all low-income children and the adults who support them. Id. States should be entrusted with health care reform just as they were allowed to experiment with welfare reform. Id. 
For example, New York's Child Health Plus (CHP) served as a model for the federal State Child Health Insurance Program (SCHIP) legislation. ${ }^{105}$ The federal legislation allows for flexibility and the states set up plans to meet their individual needs. ${ }^{106}$ State policymakers had the benefit of observing and learning from other states as they implemented their own program. ${ }^{107}$

\section{F. Issues that are Unique to a State Electorate}

\section{Health Care Reform}

True distinctions in heath care are found throughout the United States. The resolution of health care issues in the East may be vastly different from those in the West. For example, because of their widespread experience with health maintenance organizations (HMOs), Californians may be content with managed competition. ${ }^{108}$ In contrast, citizens of Vermont may find the notion of competition among large health insurance companies absurd given the small size and population of the state. ${ }^{109}$ Maryland may prefer an all-payer system for cost control because this approach has proven successful in constraining hospital costs; Kentucky has a comprehensive statewide insurance that seems to suit its population, while the greatest dilemma in Connecticut is cost escalation. ${ }^{110}$ Therefore, the possibility of meeting varied state goals in health care at the national level is improbable given the diversity of the United States.

\section{Moral Issues}

"When an issue turns solely on ethics, not science, it is reasonable to allow individual states to reach their own conclusions, rather than impose a uniform national standard through implied preemption of state medical standards." "111 The political reality is that a smaller unit of government is likely to have a population with preferences that depart from the majority's and is therefore more inclined to try an approach that could not command

105. William P. Brandon et al., Launching SCHIP: The States and Children's Health Insurance, in THE NEW POLITICS OF STATE HEALTH POLICY 151 (Robert B. Hackey \& David A. Rochefort eds., 2001).

106. Id. at 143.

107. See generally id. at 142-185.

108. Mashaw \& Marmor, supra note 62, at 116.

109. Id.

110. Id. at 116-17.

111. Joy Falleck, Note, The Pain Relief Promotion Act: Will it Spell "Death with Dignity" or is it Unconstitutional? 27 FORDHAM URB. L.J. 1739, 1753-54 (2000). (quoting letter from Robert Raben, Assistant Att'y General, U.S. Dept. of Justice, Off. of Legis. Aff., to Henry Hyde, Chairman, House Comm. on the Judiciary (Oct. 19, 1999)). 
national consensus. ${ }^{112}$ Four major and distinct regions of the United States have been identified-the Northeast, the Midwest, the South and the West - each vote very differently and diverge on matters of religion, culture, and to some extent, race and ethnicity. "The South is more religious, more culturally conservative, less Catholic, and more racially polarized in its voting behavior than the rest of the country."114 Therefore, the West may support policies such as physician-assisted suicide that are opposed by the religious, culturally conservative South. Acting on distinct cultural, social and political traditions, states can experiment with new ideas that may influence their neighbors or more importantly, satisfy their own constituents' needs.

National solutions can be the majority's moral views in disguise as the necessary uniform answer to a problem. Reacting to a call for uniform national standards, Representative Barney Frank stated that:

the existence of a right of assisted suicide in Oregon has no effect in Massachusetts or Oklahoma ... . but clearly the need for uniformity simply reflects a desire of people here to impose their moral views on the people of Oregon who have been found to be morally deficient in this particular regard. ${ }^{115}$

Federalism only has meaning if Congress exercises restraint even when it opposes state policy choices. To claim that states should be free to experiment with policy only when their experimentation reflects a national consensus, rather than their population's preferences, is really to assert that the states are merely administrative arms of the federal government. ${ }^{116}$

Issues that create division in cultural or moral belief may gain acceptance at the state level and lead to national tolerance and perhaps eventual approval. In the past, diverse state laws and eventually a Supreme Court decision ${ }^{117}$ changed state miscegenation laws and today, interracial marriage is common throughout the nation. Likewise, same-sex marriage as a constitutional matter is forcefully debated and remains divisive. When an issue divides in ways that cut to the heart of people's identities, the Court's best strategy is to leave the matter to state experimentation ${ }^{118}$ and perhaps a

112. ThE Federalist No. 10 (James Madison); see also Steven G. Calabresi, $A$ Government of Limited and Enumerated Powers: In Defense of United States v. Lopez, 94 MiCH. L. REV. 752, 761 (1995).

113. Calabresi, supra note 112, at 766-67.

114. Id. at 767.

115. Falleck, supra note 111, at 1753 (citing H.R. REP. No. 106-378, pt. 1, at 32 (1999)).

116. Id. at 1753-54. (citing Editorial, The Assisted Suicide Ban, WASH. PosT, Nov. 1, 1999, at A26).

117. Loving v. Virginia, 388 U.S. 1 (1967).

118. William N. Eskridge, Jr., Symposium, Gay Rights after Lawrence v. Texas: Article: Lawrence's Jurisprudence of Tolerance: Judicial Review to Lower the Stakes of Identity Politics, 88 MINN. L. REV. 1021, 1092 (2004). 
national solution will emerge. In fact, this is the approach the Court took in the right-to-die case, Washington v. Glucksberg, ${ }^{119}$ when it found the nation should continue the crucial debate about the morality and legality of physician-assisted suicide. ${ }^{120}$

\section{IMPORTANCE OF FEDERALISM AND RECENT SUPREME COURT DECISIONS SUPPORTING A NEW FEDERALISM}

Both in the past and today, the political debate focuses on federalism or the appropriate balance between the federal and state governments regarding health care and the extent the government should be involved at all. ${ }^{121}$ To ensure protection of the people's rights, the Constitution creates two governments rather than one. Therefore, the power is divided between the federal and state governments. The powers of the national government are limited and enumerated and the remaining powers are reserved to the states. ${ }^{122}$ Over the past 200 years, many factors led to an expansion of national power at the expense of state autonomy and are beyond the scope of this note. Still, it is pertinent to examine the benefits of federalism that are lost when power is centralized in the national government. Specifically, decentralized government with authority at the state and local level fosters greater political participation, increased accountability, and more innovation to experiment with solutions.

\section{A. Federalism Arguments}

\section{Greater Political Participation}

Voters have a greater opportunity to influence and participate in decisions that impact their lives at the state level. ${ }^{123}$ "The Framers recognized that the most effective democracy occurs at local levels of government, where people with firsthand knowledge of local problems have more ready access to public officials responsible for dealing with them. This is as true today as it

119. Washington v. Glucksberg, 521 U.S. 702, 735 (1997)(holding that Washington's ban on assisted suicide promoted an important and legitimate government interest and did not offend the Fourteenth Amendment to the United States Constitution).

120. Id. at 735 .

121. Robert F. Rich \& William D. White, Health Care Policy and the American States: Issues of Federalism, in HEALTH POL'Y, FEDERALISM, AND THE AM. STATES 3-4 (Robert F. Rich \& William D. White eds., 1996).

122. See U.S. CONST. art. I, \& 8; U.S. CoNST. amend. X (stating "[t] $]$ he powers not delegated to the United States by the Constitution, nor prohibited by it to the States, are reserved to the States respectively, or to the people.").

123. Barry Friedman, Symposium, The Law and Economics of Federalism: Valuing Federalism, 82 MINN. L. REV. 317, 390-92 (1997)(arguing that a smaller electorate brings the government closer to the people). 
was when the Constitution was adopted."124 Many health care policy choices involve issues in which intelligent citizens hold diverse, but equally rational views that are better represented by state government choices than homogenous national laws. ${ }^{125}$ Representing the entire nation at the expense of independent state policy choices destroys the political impact each citizen has on health care decisions. Many health care choices involve intimate social policy that should be decided by state voters, not by distant and remote members of Congress.

\section{More Government Accountability and Access}

A compelling argument for state responsibility for health care is that the Constitution contemplates that a state's government will represent and remain accountable to its own citizens. ${ }^{126}$ When the federal government asserts authority over a state's most fundamental political processes, it undermines political accountability. Generally, state lawmakers live in the same localities as their constituents and are personally impacted by policy choices. Further, smaller units of government "makes it far easier for citizens to exercise a greater and more effective degree of control over their government officials" ${ }^{127}$ through increased access. For this reason, it often makes sense for states to retain control over controversial social issues where government officials may be scrutinized more readily by voters. ${ }^{128}$

Justice Kennedy begins his concurring opinion in Lopez by citing the Federalist proposition that "two governments accord more liberty than one,"129 and for this to be realized, "citizens must have some means of knowing which of the two governments to hold accountable for the failure to perform a given function." 130 In Justice Kennedy's view, the role of the Court is to protect states from the intrusion of the federal government into areas of state regulation. ${ }^{131}$ Unless a balance is preserved, "the boundaries between the spheres of federal and state authority would blur and political responsibility would become illusory."132

124. Garcia v. San Antonio Metro. Transit Auth., 469 U.S. 528, 576 n. 18 (1985) (Powell, J., dissenting) (citing THE FEDERALIST No. 17, 46).

125. Grant S. Nelson \& Robert J. Pushaw, Jr., Rethinking the Commerce Clause: Applying First Principles to Uphold Federal Commercial Regulations but Preserve State Control Over Social Issues, 85 IowA L. REV. 1, 118(1999)(stating that federal standards wipe out differences of opinion on social, cultural, or moral issues and that diversity of views should be encouraged, and the only realistic means to do so is through state and local legislation).

126. Lopez, 514 U.S. at 576-77 (citing THE FEDERALIST No. 51, 46).

127. Calabresi, supra note 112, at 778.

128. Id.

129. 514 U.S. at 576 (Kennedy, J. concurring) (discussing THE FEDERALIST No. 51).

130. Id. at 576-77.

131. Id. at 576-78.

132. Id. at 577 . 
A uniform national solution to health care issues very easily can become a solution that is not tailored to anyone. Furthermore, policymaking at the national level makes it difficult for those communities which suffer from policy errors or oversights to get their concerns addressed. ${ }^{133}$ The majority of a state may be a national minority and their political voice can be deafened.

Health care decisions should be made at the state level because health care policy choices must reflect the consensus of the population and decisionmakers should be accountable. ${ }^{134}$ It is easier to achieve consensus on a small scale and in the United States system, the state represents the clearest form of community. ${ }^{135}$ As the nation faces tough decisions in health care, true solutions will not come without the consent of the greatest number of citizens, which is more likely at the state level.

\section{State Experimentation}

A closely related argument and the primary focus of this note is that state diversity and experimentation are vital to health care. State and region differences are evident in the current choices concerning Medicaid and state laws governing controversial health care issues. ${ }^{136}$ Undeniably, there is diversity in health care and individual states should be allowed to adopt laws and pursue policies that reflect their different preferences. ${ }^{137}$ Beyond mere accommodation of social, political, or cultural differences, state diversity encourages states to experiment with their policies. ${ }^{138}$

Indeed, necessary innovation may present a better picture of the reality of state experimentation because rather than a carefully planned experiment, often state officials are solving real problems staring them in the face. ${ }^{139}$ Innovation becomes an evolutionary process as state and local governments develop different strategies for solving problems and learn from each other. ${ }^{140}$ Through observation and communication, techniques employed in other locales are shared and the most attractive solutions can be adopted by other states while the less effective solutions are avoided. ${ }^{141}$ Just as in any facet of life, better solutions develop as we learn from our mistakes and the experiences of others.

133. Jonathan $\mathrm{H}$. Adler, Comment, The Green Aspects of Printz: The Revival of Federalism and its Implications for Environmental Law, 6 GEO. MASON L. REv. 573, 629 (1998). See Printz v. United States, 521 U.S. 898 (1997) (stating this concern for political accountability).

134. Laguarda, supra note 82, at 190.

135. Id.

136. WEISSERT \& WEISSERT, supra note 83.

137. Harry N. Scheiber, Dedication: Forward: The Direct Ballot and State Constitutionalism, 28 RUTGERS L. J. 787, 805 (1997).

138. Id. at 804.

139. Friedman, supra note 123, at 398.

140. Id. at 400 .

141. Id. 
Brandeis warned, "[t]o stay experimentation in things social and economic is a grave responsibility. Denial of the right to experiment may be fraught with serious consequences to the Nation."142 As noted earlier, the Supreme Court called for just this type of continued state-by-state social experimentation in Washington $v$. Glucksberg. ${ }^{143}$ Residents of Oregon should be permitted to employ physician-assisted suicide to refine its guidelines and monitor its results; and California residents should be allowed to test the policy implications of medicinal marijuana and support embryonic stem cell research while the nation watches from the sidelines. Then voters can determine, state by state, the appropriateness of these social policies.

\section{Health Care-Area Traditional Regulated by States}

It was the deliberate intent of the Constitutional framers to entrust the police power or the protection of public health, safety, and morals to the states and the federal government with less sensitive powers like those over interstate commerce. ${ }^{144}$ "Moral issues . . . are best left to the States, precisely as the Founders intended"145 and given the variety of views concerning issues of morality, the protection of liberty supports decentralized decisionmaking. ${ }^{146}$

States are self-interested parties as major regulators, payers, and sources of health care; approximately twenty-seven percent of state budgets are spent on health care ${ }^{147}$ and health-related programs. ${ }^{148}$ Furthermore, states have traditionally been left to form their own policies regarding the delivery of health care in vital and controversial areas. ${ }^{149}$

In Lopez, the Court stated that if Congress were permitted to regulate areas where States have historically been sovereign, then "it is difficult to perceive any limitation on federal power, even in areas such as criminal law enforcement or education ....."150 This statement supports the Court's protection of state sovereignty in traditionally state-regulated areas. "In

142. New State Ice Co., 285 U.S. at 311 (Brandeis, J., dissenting).

143. Washington v. Glucksberg, 521 U.S. 702 (1997).

144. Michael W. McConnell, Review, Federalism: Evaluating the Founder's Design, 54 U. CHI. L. REV. 1484, 1506 (1987) (stating the "Dred Scott decision, employing the pernicious doctrine of substantive due process to vitiate Congress's power to deal with the slavery question, upset the constitutional scheme and thus made civil war unavoidable.").

145. Id. (quoting Raoul Berger, FEDERALISM: THE FOUNDERS' DESIGN (1987)).

146. Id.

147. Nat'l Assoc. of State Budget Officers, 2003 State Expenditure Report (Oct. 2004), available at http://www.nasbo.org/Publications/PDFs/2003ExpendReport.pdf. In 2003, over twenty-one percent of state budgets went to Medicaid expenditures. Id.

148. FEDERALISM \& HEALTH POLICY, supra note 56.

149. Newbern, supra note 11.

150. Lopez, 514 U.S. at 564. 
addition to criminal law enforcement and education, health care regulation is an area where states historically have been sovereign." 151

\section{B. Federalist Supreme Court Decisions}

\section{The Role of the Court}

There is pressure on Congress to appear responsive to every highly publicized societal problem and this must be balanced with an inquiry into whether our policies should be determined at the national or local level. ${ }^{152}$ Perhaps the Court's approach to federal and state conflicts should not be complete deference to Congress because state interests are not always sufficiently represented. Inadequate state representation in the political process exists when interest group activity overpowers the accountability of Congress to the states, as it does in the area of health care. ${ }^{153}$ While judicial activism is not a defensible position, as the federal government blurs the lines of accountability and regulates in areas constitutionally reserved to the states, the Court must protect state sovereignty.

The constitutional or legal foundations for federalism deal primarily with interpreting the Tenth and Eleventh Amendment and the Commerce Clause. The Court's recent decisions in interpreting the Commerce Clause and its decisions in Tenth and Eleventh Amendment cases ${ }^{154}$ suggest that the Constitution does provide independent state government authority and the Court is willing to protect states' rights. ${ }^{155}$ First, the Court has shown its willingness for the first time since 1937 to police the boundary between congressionally enumerated powers regulating commerce and the enforcement of the Fourteenth Amendment. ${ }^{156}$ Second, the Court has enforced a Tenth

151. Batt, supra note 33, at 316 (quoting Lopez, 514 U.S. at 564).

152. William H. Rehnquist, The 1998 Year-End Report of the Federal Judiciary (Nov./Dec. 1998), available at http://www.uscourts.gov/ttb/jan99ttb/january1999.html\#e.

153. Laguarda, supra note 82, at 190-91 (arguing that interest group lobbying at the federal level overshadows state interests because states do not have the money). See New York v. United States, 505 U.S. 144, 188 (1992) (invalidating provisions of a federal law that required states to take title to low-level radioactive waste or to regulate in accordance with Congressional restraints).

154. Other recent Supreme Court cases reinforcing federalism include: City of Boerne v. Flores, 521 U.S. 507 (1997) (holding that the Supreme Court, not the Congress, determines the scope of Congress' enforcement power under the Fourteenth Amendment); Seminole Tribe of Florida v. Florida, 517 U.S. 44 (1996) (holding Congress lacks the authority to abrogate states Eleventh Amendment immunity from liability); Cipollone v. Liggett Group, Inc., 505 U.S. 504 (1992) (holding that state police powers will not be superseded by federal law without explicit evidence of Congressional intent); Gregory v. Ashcroft, 501 U.S. 452 (1991) (upholding state constitution's mandatory retirement age for judges).

155. Rich \& White, supra note 121, at 8-9.

156. See United States v. Morrison, 529 U.S. 598 (2000); City of Boerne v. Flores, 521 U.S. 507 (1997); United States v. Lopez, 514 U.S. 549 (1995). 
Amendment barrier forbidding Congress' commandeering of states. ${ }^{157}$ Third, the Court has created an obstacle to Congress' efforts to expose states to private lawsuits by expanded sovereign immunity. ${ }^{158}$ Collectively, these recent cases denote an obvious departure from the Court's prior case law; states have not received such Court protection from the federal government since before the New Deal. ${ }^{159}$

\section{Commerce Clause-Lopez and Morrison Decisions}

In 1995, the Court's landmark decision in Lopez was the first significant limitation on Congress' power under the Commerce Clause in sixty years. ${ }^{160}$ In 2000, the Court's resolve to limit Congress' ability to use the Commerce Clause to regulate areas constitutionally reserved for the States was reaffirmed in United States $v$. Morrison. ${ }^{161}$ Because the Commerce Clause arguably does not grant Congress this authority, it is now rational to question the basis of Congress' power to regulate intrastate activities such as medicinal marijuana, partial-birth abortion, embryonic stem cell research, physician-assisted suicide and state reform efforts. ${ }^{162}$

Lopez and Morrison generate the principles that serve as the current standard for evaluating Congress' Commerce Clause authority. The Court's resolve to maintain a bright-line separation between the jurisdiction of federal and state power is apparent. ${ }^{163}$ Now, a concrete showing that an activity is economic in nature and that it substantially affects interstate commerce is necessary before the federal government can regulate intrastate activity. ${ }^{164}$ The Court found "we would have to pile inference upon inference in a manner that would bid fair to convert congressional authority under the Commerce Clause to a general police power of the sort retained by the States."165 The Court will no longer defer to Congress in providing such proof, and if no more than a tenuous connection can be made, the activity will be left to the states. ${ }^{166}$

157. See Printz v. United States, 521 U.S. 898 (1997); New York v. United States, 505 U.S. 144 (1992).

158. See Seminole Tribe v. Florida, 517 U.S. 44 (1996).

159. Calabresi, supra note 4, at 25.

160. Newbern, supra note 11 , at 1579.

161. Morrison, 529 U.S. at 626-27.

162. Newbern, supra note 11, at 1579.

163. See United States v. Lopez, 514 U.S. 549 (1995).

164. Id.

165. Id. at 567 .

166. Id. at 581 . 


\section{Tenth Amendment-New York and Printz Decisions}

Both, New York v. United States ${ }^{167}$ and Printz v. United States ${ }^{168}$ place limits on Congress' ability to commandeer the states. In New York, the Court held that Congress could not force states to adopt a plan for the disposal of radioactive waste and to allow such force would be to erroneously "commandeer the legislative processes of the States."169 In Printz, the Court held that Congress could not compel local law enforcement officers to perform background checks as part of the requirements of the Brady Bill's handgun regulations. ${ }^{170}$ These decisions indicate a shift in the Court's Tenth Amendment analysis and an invalidation of the federal government's ability to force the states to enact or enforce laws. Chief Justice Rehnquist's reference to this line of precedent in Lopez may indicate a larger philosophical shift of the Court towards upholding state control over traditional state functions. ${ }^{171}$

Likewise, the Court's decision in Gregory v. Ashcrof $t^{172}$ indicates that the federal courts have a duty to be certain of Congress' intent before allowing federal law to preempt state law and override the balance of state and federal power. Otherwise, these acts serve to undermine the state government's accountability and upset the balance between state and federal government. ${ }^{173}$

\section{Eleventh Amendment-Seminole Tribe Decision}

Another federalism shift occurred on the issue of Congress' power to disregard state sovereign immunity under the Eleventh Amendment. Seminole Tribe v. Florida overruled the Court's 1989 Pennsylvania v. Union Gas Company ${ }^{174}$ decision, which stood for the short-lived principle that Congress could circumvent the Eleventh Amendment by using statutes passed under the Commerce Clause to allow a private citizen to file suit against a state in federal court. ${ }^{175}$ The Eleventh Amendment restricts the judicial power under Article III, and Congress cannot use Article I to escape the constitutional limitations placed upon the federal government. ${ }^{176}$ The Court continued to

167. New York v. United States, 505 U.S. 144 (1992).

168. Printz v. United States, 521 U.S. 898 (1997). Printz was not under the Court's consideration when the Lopez decision was opined.

169. New York, 505 U.S. at 161.

170. Printz, 521 U.S. at 935.

171. Newbern, supra note 11, at 1617-18.

172. Gregory v. Ashcroft, 501 U.S. 452, 469 (1991) (holding that Congress did not demonstrate a clear intent to infringe upon traditional state power to prescribe qualifications for its officers when enacting the Age Discrimination Employment Act).

173. New York, 505 U.S. at 168-69.

174. Pennsylvania v. Union Gas Company, 491 U.S. 1 (1989).

175. Seminole Tribe, 517 U.S. at 47.

176. Id. at $72-73$. 
rely upon the Eleventh Amendment to limit congressional power over states in other cases and suggested Congress allow the states to fashion their own remedies before enacting federal power. ${ }^{177}$ This represents an obvious shift in the Court's proclivity to use the Commerce Clause as a basis for infringing on the states' autonomy. Still, state sovereignty is not secure from federal government intrusion because the Court's federalist opinions are narrow enough to allow Congress to use its spending power to address the same issues. ${ }^{178}$

\section{Strange Bedfellows for States' Rights-Supporting Ends Rather than Means}

Although Congress' power has arguably been curtailed, proponents of state initiatives such as medicinal marijuana and PAS have not defended these initiatives by pointing out the limits of the Commerce Clause. Instead, these issues are debated almost exclusively in the area of public policy. Most likely this is because those who would benefit most from pointing out the potential impact of Lopez on these issues are the same parties who support expansive federal power on other issues. ${ }^{179}$ In fact, these parties would object vigorously to the limitation of the federal government's power in other debates, especially individual rights' cases. ${ }^{180}$ Lopez has made strange bedfellows in the federalism debate; its impact on a wide range of issues including PAS, medicinal marijuana and partial-birth abortion will depend upon the evershifting political climate surrounding these issues.

There is political rhetoric, however, on both sides of the aisle and federalism often provides a useful tool for proponents on either side to frame a debate. Indeed, federalism often is instrumental when there is a disagreement over basic social or political issues. For example, gun owner and manufacturer advocates espoused state sovereignty arguments to challenge the Brady Handgun Violence Prevention Act, which required local law enforce-

177. See Newbern, supra note 11 , at 1616-17.

178. Neal Devins, The Federalism- Rights Nexus: Explaining Why Senate Democrats Tolerate Rehnquist Court Decision Making But Not the Rehnquist Court, 73 U. CoLo. L. REV. 1307, 1314-15 (2002).

179. See Rory K. Little, Myths and Principles of Federalization, 46 HASTINGS L.J. 1029, 1065 (1995) (stating many liberals oppose the federalization of crime because of the severity of federal criminal Sentencing Guidelines, but are reluctant to support states' rights federalism arguments suggestive of anti-civil rights arguments that were successfully battled decades ago); David B. Kopel \& Glenn H. Reynolds, Taking Federalism Seriously: Lopez and the PartialBirth Abortion Ban Act, 30 CoNN. L. REV. 59, 60 (1997) (discussing a similar political irony faced by those opposed to a federal ban on late-term abortions which might be invalid under Lopez, but who are advocates of expansive federal power on other issues).

180. Little, supra note 179. 
ment officials to conduct criminal background checks on handgun buyers. ${ }^{181}$ Still, gun owners and manufacturers probably would not support states' rights as vigorously should states begin to enact strict gun control laws. ${ }^{182}$ Likewise, politically charged health care policy issues force advocates to embrace either state autonomy or federal preemption arguments depending on the nature of the threat. For instance, both pro-choice advocates and federalists may oppose a federal partial-birth abortion ban; the pro-choice advocate because it limits treatment options by physicians and the federalist because the ban preempts areas traditionally reserved to the states-family and health. ${ }^{183}$ Therefore, health care federalism support is often a product of the political ends, which in the long-run is counterproductive to many reforms because the underlying motivation is not at all related to health care solutions.

\section{CURRENT STATE OF HeAlth CARE IN THE UNITED STATES}

\section{A. Need for Reform}

So where does all this political rhetoric lead us? Depending on the political context, sometimes the United States is said to have a health care crisis. Subsequently, the drive for a national health care solution is a result of escalating health care costs and the growing number of uninsured.

\section{Cost of Health Care}

In 2002, the United States spent $\$ 1.6$ trillion on health care, an amount more than five times as great in real terms as that spent in $1970 .{ }^{184}$ As the federal government faces greater pressure to decrease spending, states are left to formulate health care solutions for their citizens. ${ }^{185}$ Today, twenty-seven

181. Brian E. Bailey, Note, Federalism: An Antidote to Congress's Separation of Powers Anxiety and Executive Order 13,083, 75 IND. L.J. 333, 343-44 (2000) (citing Pub. L. No. 103159,107 Stat. 1536 (1993) (codified at 18 U.S.C. $\$ 922(\mathrm{~s})$ (1994)).

182. Id. at 343 .

183. Id. at 344.

184. Congesssional Budget Office, $C B O$ Testimony on Health Care Spending and the Unisured (Jan. 28, 2004), available at http://www.cbo.gov/showdoc.cfm?index $=4989 \&$ sequence $=0$. While the economy as a whole has grown over that period as well, its growth has been slower; with the result that health spending as a percentage of gross domestic product has more than doubled, from $7.0 \%$ in 1970 to $14.9 \%$ in 2002 . Id. Federal spending on health care, predominantly Medicare and Medicaid, is subject to the same cost pressures facing the system as a whole. Id. Total federal health spending as a percentage of GDP was 1.7 in 1970 and 4.8 in 2002. Id. Under an optimistic assumption, federal Medicare and Medicaid spending would reach $11.5 \%$ of GDP in 2050 . Id. To put those estimates in perspective, the entire federal budget currently consumes $20 \%$ of GDP. Id.

185. Rich \& White, supra note 57, at 875 (stating under Medicaid, states were offered the option either of covering new groups or pulling out of the program entirely). 
percent of total state budgets are consumed by health care services. ${ }^{186}$ The escalation of the cost of health care is multi-faceted and beyond the scope of this note. Regardless, the over consumption of a scarce resource by consumers and the desire for the most technologically advanced and often the most expensive care is a problem the United States must address. ${ }^{187}$ Additional factors of managed care, ${ }^{188}$ malpractice litigation, ${ }^{189}$ and defensive medicine ${ }^{190}$ also are cited as contributing factors to rising health care costs in the United States.

\section{Uninsured Population}

It is frequently stated that about forty million Americans lack health insurance coverage. While this estimate, by itself, presents an incomplete and potentially misleading picture of the uninsured population, the number of uninsured is a critical factor driving the national debate for health care reform.

Reality suggests that the uninsured population is constantly changing as people gain and lose coverage. Furthermore, people vary greatly in the length of time that they remain uninsured. ${ }^{191}$ Some people are uninsured for long periods of time, but more are uninsured for shorter periods. The Congressional Budget Office's ("CBO") recent analysis found that in 1998 somewhere between twenty-one and thirty-one million people were uninsured all year, forty million people were uninsured at any given point during the year and nearly sixty million people were uninsured at some point during the year. ${ }^{192}$ Even so, health insurance coverage by income shows that twenty percent of those uninsured have incomes over $\$ 50,000,{ }^{193}$ which may suggest that Americans in higher income brackets are opting out of insurance based on their own risk assessment. Further, in 2000, sixty-nine percent of uninsured

186. FedERALISM \& HeALTH Policy, supra note 56.

187. Mark Hall, Making Medical Spending Decisions: The Law, Ethics, and Economics of Rationing Mechanisms, in THE LAW OF HEALTH CARE FINANCE AND REGULATION 79 (Mark A. Hall et al. eds., 2005).

188. CMS-Update, supra note 66. Two-thirds of commercially insured Americans were in Preferred Provider Organizations and Point of Service plans, while one-fourth are in Health Maintenance Organizations. Id.

189. CBO-Economic, supra note 67. "Malpractice costs amounted to an estimated \$24 billion in 2002, but that figure represents less than two percent of overall health care spending ...."Id.

190. McGovern \& Simpson, supra note 68. "Reputable studies estimate that this 'defensive medicine' squanders $\$ 50$ billion a year ...." Id.

191. Congressional Budget Office, $C B O$ Testimony: Health care spending and the Uninsured (Jan. 28, 2004), available at http://www.cbo.gov/showdoc.cfm?index $=4989 \&$ sequence $=0$ (last visited Aug. 4, 2005) (based on information obtained in 1998).

192. Id.

193. Public Agenda, Health Care: Fact File, at http://www.publicagenda.org/ issues/factfiles_detail.cfm?issue_type=health care\&list $=10$ (last visited Oct. 31, 2005) (based on US Census information obtained in 2003 for 2002 statistics). 
were adults and forty-nine percent were white. ${ }^{194}$ While a strong argument can be made that the majority of uninsured are not poor minority children as the political rhetoric suggests, politicians are still motivated to satisfy constituents' perceptions of the crisis.

\section{B. Political Solution-Calling for a National Health Care System}

\section{Political Stalemate at the National Level}

Today, the United States stands alone as the only industrial nation in the world without universal access to health care. ${ }^{195}$ Perhaps, "[ $\left.t\right]$ his alone suggests that there are factors that make the delivery of health care in the U.S. [sic] too complex to administer on a national scale."196 Conceivably, citizens believe that national uniformity for a diverse country like the United States is not practical or preferable. After all, the United States is a nation that celebrates individualism and diversity. Still, the call for universal health care is not a new phenomenon. Since the Second World War, comprehensive national reform has been attempted multiple times, but has not achieved political majorities. ${ }^{197}$ While there are particularized factors contributing to previous failures, ultimately our political system has not produced a solution that satisfies enough of the people to surmount the other barriers to health care reform. ${ }^{198}$

This stalemate is a result of the improbability that any single system is "best" for the whole nation. ${ }^{199}$ "Regions, states, even localities, differ in their demographic characteristics, political cultures, existing styles of medical practice, and appetites for medical services."200 Therefore, what is desirable for any one state varies enough to make state autonomy attractive and politically wise as an alternative to a national solution. ${ }^{201}$ In support of this proposition, one needs look no further than the independent state initiatives passing medicinal marijuana, PAS and stem cell research legislation.

Several advocates of cooperative federalism support ending the stalemate by offering a federally funded "tool box" of options to states to

194. Centers for Medicare \& Medicaid Services, An Overview of The U.S. Health Care System: Two Decades of Change 1980-2000 (Chapter 5), available at http://www.cms.hhs.gov/ charts/healthcaresystem/chapter5.pdf (lasted visited Nov. 21, 2004).

195. Julia Vaugh, What About the Uninsured? Ethics News, Indiana Healthcare Ethics Network. Vol. 3. (1999), available at Citizens Action Coalition of Indiana, http://www.citact.org/uninsured.htm. "Today, the United States stands alone, since South Africa enacted a universal health program in 1996." Id.

196. Litman, supra note 64 , at 875.

197. Mashaw \& Marmor, supra note 62, at 115-116.

198. Id. at 115-116.

199. Id. at $116-117$.

200. Id. at 117.

201. Id. 
reduce the number of uninsured through innovation in health care reform without any strings attached. ${ }^{202}$ This partnership would enable the states to undertake innovative approaches to health care challenges facing the nation. In health care as well as education or welfare, states have been the primary innovators and by actually testing competing approaches to reach common goals, rather than endlessly debating them, America is far more likely to find solutions to its health care problems. ${ }^{203}$

\section{Voter Reluctance to Support a National Health Care Plan}

American voters have not supported a federal health care plan at the ballot box. Congress failed to pass universal health care during the Clinton Presidency and Senator Kerry's health care reform platform, among other things, failed to sway the American people with his defeat in the 2004 election. "[I]n a nation where only two out of every ten citizens believe that the government "will do the right thing most of the time"" 204 it is not surprising that the American people are reluctant to allow the federal government to regulate such an important aspect of life.

The most serious criticism of the Clinton health care reform plan was that it required too much governmental oversight and that such regulation of medicine would result in decreased quality of service. ${ }^{205}$ At this point, proceeding with the status quo has been the political solution of choice. A government attempt to provide universal access without careful consideration of the choice and extent of services for those it intends to insure will result in decreased quality, ${ }^{206}$ which is something voters have not been willing to sacrifice.

\section{The Medicare EXAMPLE Of FEDERALIZEd HEALTH CARE}

Medicare provides the best example of the federal government's ability to regulate a universal health care plan at the national level. Therefore, a study of this program is useful to analogize the effect of a national health care plan.

202. Henry J. Aaron \& Stuart Butler, How Federalism Could Spur Bipartisan Action on the Uninsured (Sept. 19, 2003), available at http://sihp.brandeis.edu/council/pubs/ Health\%20Insurance\%20Expansions\%202004/Aaron\%20Butler\%20September\%20Council \%20sept\%203\%20version.pdf.

203. Id.

204. Litman, supra note 64 , at 876.

205. Id.

206. Judith M. Rosenberg \& David T. Zaring, Managing Medicaid Waivers: Section 1115 and State Health Care Reform, 32 HARV.J. ON LEGIS. 545, 547-53 (1995)(stating that managed care waivers were not the intention of 1115 and will lead to a poorer quality of care). See Litman, supra note 64 , at 876. 


\section{A. The Social Security Act}

When Congress created the Medicare program in 1965, its purpose was to provide hospital and medical insurance for persons over the age of sixtyfive, not to accomplish broad societal goals. ${ }^{207}$ In fact, Congress made clear its intent that Medicare funds should not be used for the benefit of nonMedicare patients. ${ }^{208}$ Over time however, Congress has expanded Medicare to promote broader public goals such as providing indigent care and supporting rural health facilities and graduate medical education. ${ }^{209}$ Medicare expansion often is achieved by using participation in the program as a hook to impose unfunded mandates that apply to non-Medicare patients also. ${ }^{210}$ Moreover, the federal government did not expand Medicare in a calculated manner to accomplish an identified goal, but rather has been reactionary to a series of largely unrelated matters. ${ }^{21}$

The irony is that Congress itself declared its intention to prohibit federal interference with state medical practices in the preamble to the Health Insurance for the Aged Act: Medicare. It states:

[p]rohibition against any Federal interference. Nothing in this title [42 USCS $\S \S 1395$ et seq.] shall be construed to authorize any Federal officer or employee to exercise any supervision or control over the practice of medicine or the manner in which medical services are provided ... or to exercise any supervision or control over the administration or operation of any such institution, agency, or person. ${ }^{212}$

\section{B. Spending Power}

Congress utilizes Medicare as a tool to achieve broad social policy goals by means of its spending power and attaching conditions to the receipt of federal funds. The Constitution gives Congress the power to "lay and collect Taxes ... to pay the Debts and provide for the common Defence and general

207. See Social Security Amendments of 1965, Pub. L. No. 89-97, 79 Stat. 286 (codified as amended in scattered sections of 42 U.S.C.). H.R. REP. No. 89-213 (1965); S. REP. No. 89404 (1965) (reprinted in 1965 U.S.C.C.A.N. 1943); CONF. REP. No. 682 (1965) (reprinted in 1965 U.S.C.C.A.N. 1943).

208. Dean M. Harris, Symposium, The Future of Medicare, Post Great Society and Post Plus-Choice: Legal and Policy Issues: Beyond Beneficiaries: Using the Medicare Program to Accomplish Broader Public Goals, 60 WASH \& LEE L. REV. 1251, 1312 (2003).

209. Id.

210. Id. See discussion infra Part V.D.

211. Id.

212. 42 U.S.C. $\S 1395$ (2005). 
Welfare of the United States." 213 This section confers upon Congress the power to tax and spend, however, the power to tax is explicit and the spending power is an amalgamation of judicial decisions. In United States v. Butler, ${ }^{214}$ the Supreme Court construed the phrase "provide for the ... general Welfare" to mean Congress has the power to tax "for the purpose of providing funds... for the general welfare,"215 or Congress has the power to spend taxpayers dollars for the general welfare. Congressional power to spend is not limited by legislative power in the Constitution; ${ }^{216}$ rather restrictions on the spending power are limited by the broad interpretation that spending supports the general welfare. ${ }^{217}$

Today, the spending power enables Congress to indirectly accomplish policy objectives which it could not accomplish directly under powers granted by the Constitution. ${ }^{218}$ Attaching conditions to the receipt of federal funds, Congress exercises broad control over states' and private entities' activities frequently. ${ }^{219}$

Unlike the Commerce Clause, the Supreme Court has not limited Congress' spending power. In Rust v. Sullivan, the Court held that "when the Government appropriates public funds to establish a program it is entitled to define the limits of that program."220

In South Dakota v. Dole, ${ }^{221}$ the leading spending clause case, the Court affirmed that Congress has wide latitude to exert federal power by attaching conditions in order to participate in federal programs. In Dole, South Dakota challenged a federal statute withholding a percentage of federal highway funds from states that maintained lawful drinking ages below twenty-one. Synthesizing the law of previous decisions, the Court found only four limitations upon the spending power: (1) the exercise of power must be in furtherance of the general welfare; (2) conditions imposed upon the receipt of federal funds must be unambiguous, enabling the recipient to make a choice

213. U.S. CoNST. art. I, $\S 8$, cl.1.

214. United States v. Butler, 297 U.S. 1, 64 (1936).

215. Id.

216. Id. at 65-66.

217. Helvering v. Davis, 301 U.S. 619,640 (1937).

218. Andrew Jay McClurg, Your Money or Your Life: Interpreting the Federal Act Against Patient Dumping, 24 WAKE FOREST L. REV. 173, 229-30 (1989).

219. Id. See, e.g., National Highway Safety Act, 23 U.S.C. § 402 (a) (2005) (requiring states have a highway safety program approved by the Secretary); Rehabilitation Act of 1973, 29 U.S.C. $\$ 794$ (2005) (prohibiting discrimination against person by reason of handicap in any program receiving federal funds); Public Works Employment Act of 1977, 42 U.S.C. § 6705(f)(2) (2005) (requiring that at least ten percent of federal funds allocated under the act be used to procure services from minority businesses).

220. Rust v. Sullivan, 500 U.S. 173, 194 (1991) (upholding the health department regulations limiting the ability of Title $X$ fund recipients to engage in abortion-related activities and stating that preventing a physician from giving abortion information if receiving Title $\mathrm{X}$ funds does not violate the First or Fifth Amendments). Id.

221. South Dakota v. Dole, 483 U.S. 203 (1987). 
with knowledge of the consequences; (3) the conditions must be related or relevant to the federal interest in the particular national project or program; and (4) the conditional grant of funds must not conflict with any independent constitutional provision. ${ }^{222}$ South Dakota relied on the fourth limitation, claiming the condition conflicted with the Twenty-First Amendment, which gives the states broad power to impose restrictions on the sale and distribution of alcoholic beverages. ${ }^{223}$ The Court rejected that claim and held that Congress did not use its power to induce the States to engage in activities that would themselves be unconstitutional. ${ }^{224}$

Amici, which included several states, urged the Court to use Dole as a vehicle for establishing a rule that provides for the receipt of federal funds are legitimate only if they directly relate to the purpose of the expenditure. ${ }^{225}$ The Court, however, declined to apply this direct relationship test and in a footnote stated that "we do not address whether conditions less directly related to the particular purpose of the expenditure might be outside the bounds of the spending power."226 This footnote may leave the door open for the Court to declare a condition attached to federal funds unconstitutional when it is insufficiently related to the purpose of the expenditure. ${ }^{227}$ Still, if the Court were to adopt the direct relationship test, Dole is illustrative of how distant a connection the Court is willing to accept as satisfying the test. ${ }^{228}$ On a positive note, Justice O'Connor's dissent in Dole endorsed the position that "Congress has no power under the Spending Clause to impose requirements on a grant that go beyond specifying how the money should be spent." 229

The Court has not completely defined the extent to which Congress may place conditions on spending grants. Instead, the Court has relied on the coercion test ${ }^{230}$ which is incapable of invalidating any conditional spending provision. ${ }^{231}$ Thus, the coercion test has allowed Congress to use grants as a means of avoiding constitutional restrictions on its powers. ${ }^{232}$ The Court can close this loophole by limiting the conditions attached to federal spending programs to those that are directly related to the objective of the expenditure. ${ }^{233}$ Congress' use of the spending power has affected political accountability, the Tenth Amendment, and the balance of power between state

222. Id. at 207-08.

223. Id. at 209.

224. Id. at 211.

225. Id. at 209 n.3.

226. Id.

227. McClurg, supra note 218, at 231.

228. Id.

229. Dole, 483 U.S. at 215- 16 (O'Connor, J., dissenting).

230. See discussion infra Part VI.B.

231. Donald J. Mizerk, Note, The Coercion Test and Conditional Federal Grants to the States, 40 VAND. L. REV. 1159, 1193 (1987).

232. Id.

233. Id. at 1194 (citing Texas v. United States, 730 F.2d 339, 355 (5th Cir. 1984)). 
and federal governments. ${ }^{234}$ When determining whether federal grants to the states are constitutional, the Court should not simply decide that the states have the option to refuse the benefit and avoid any restriction. ${ }^{235}$ Instead, the Court should first determine whether Congress has the power to place the restriction on the states. ${ }^{236}$

Even as the Court narrows the outer boundaries of federal power, Congress' ability to regulate broadly through conditional spending is assumed, which serves to reassure those troubled by the Court's supposed anti-federal direction. When, for instance, the Court in Printz invalidated provisions of the Brady Handgun Violence Prevention Act on Tenth Amendment grounds, Justice O'Connor quickly noted in her concurring opinion that "[the Court's] holding . . . does not spell the end ... [to] the Brady Act ... . [because] Congress is . . . free to amend the interim program to provide for its continuance on a contractual basis with the States if it wishes, as it does with a number of other federal programs."237 Although the Commerce Clause is not powerless, the spending power is the true strength of federal control, especially in the context of health care which relies heavily on federal funding. ${ }^{238}$

\section{Public Funds and Grants}

The grant system enables the federal government to regulate state governments and impose conditions on the private providers of social services. ${ }^{239}$ As a condition of grants, Congress can demand compliance with its socioeconomic, administrative and fiscal policies. ${ }^{240}$ Since the Court's federalism decisions make direct federal regulation of the states increasingly difficult, the power of these grants as policy tools is especially attractive now. ${ }^{241}$ A conditional grant falls within Congress' Article I spending power; and because it is a carrot that a state can refuse, rather than a stick that it cannot, even grants that require states to pass legislation are not considered to be unconstitutionally coercive. ${ }^{242}$ The grant allows the federal government to purchase services for third parties and regulate the delivery of those services simultaneously. ${ }^{243}$

234. $I d$.

235. Id.

236. $I d$.

237. Printz, 521 U.S. at 936 (O'Connor, J., concurring).

238. Outterson, supra note 7, at 538-39. (2000).

239. Jody Freeman, Symposium, The Contracting State, 28 FLA. ST. U. L. REV. 155, 167

240. Id.

241. Id.

242. Id. at 167-68 (citing Dole, 483 U.S. at 211-12 (differentiating between financial "encouragement" and financial "coercion")).

243. Id. at 168. 
For example, when a state receives Medicaid funds, it must adhere to various provisions of the Social Security Act, the Balanced Budget Act, and a host of federal regulations promulgated by the Department of Health and Human Services ("HHS"). ${ }^{244}$ Compliance with these requirements is a condition of receiving the program funds. The relationship between the federal agency responsible for Medicaid oversight and the health care providers delivering care to Medicaid patients is dependent on a web of regulation. ${ }^{245}$ Through a series of multi-layered contractual agreements the federal government exercises coercive power over the delivery of health care. ${ }^{246}$

\section{Supporting Broader Federal Policy Goals}

\section{Regulations for Medicare Participation}

Medicare and Medicaid participation is a device often employed by the federal government to enforce compliance when it lacks the constitutional power to otherwise control states or private entities. For instance, when the federal administration was faced with California law legalizing medicinal marijuana, it proposed enforcement strategies such as suspending the medical licenses of all physicians who prescribed marijuana to their patients, or making those physicians ineligible for Medicare and Medicaid participation. ${ }^{247}$ Many physicians conceded that these threats would prevent them from recommending the drug. ${ }^{248}$

As another example, a majority of states on their own accord have enacted inquiry laws that require hospital administrators to discuss with next of kin the option of donating organs of a decedent. ${ }^{249}$ Still, the federal government has denied Medicare participation to hospitals that fail to "assure that families of potential organ donors are made aware of the option of organ or tissue donation and their option to decline ..."250 These participation regulations, however, are not limited to Medicare patients.

244. See 42 U.S.C. $\S 1396$ (2004); 42 C.F.R. $\S \S 430-56$ (2005).

245. Freeman, supra note 239, at 169.

246. Id.

247. Newbern, supra note 11, at 1577 (citing William Claiborne, Federal Warning on Medical Marijuana Leaves Physicians Feeling Intimidated, WASH. POST, Jan. 1, 1997, at A6).

248. Id.

249. Theodore Silver, The Case for a Post-Mortem Organ Draft and a Proposed Model Organ Draft Act, 68 B.U. L. REV. 681, 707-08 (1988).

250. 42 U.S.C. $\S 1320 \mathrm{~b}-8$ (a)(1)(A)(i)(2005). The statute provides, in part:

(1) The Secretary shall provide that a hospital meeting the requirements of subchapter XVIII or XIX ... [is eligible for certain types of federal funding and reimbursement programs] only if $(A)$ the hospital establishes written protocols for the identification of potential organ donors that (i) assure that families of potential organ donors are made aware of the option of organ or tissue donation and their option to decline, (ii) encourage discretion and sensitivity with respect Id. to the circumstances, views, and beliefs of such families ... 


\section{Arbitrary Medicare Regulations}

Congress enacted the Emergency Medical Treatment and Active Labor Act in 1986 (EMTALA), ${ }^{251}$ that requires hospitals to accept emergency cases and women in labor in order to participate in the Medicare program. ${ }^{252}$ If a hospital fails to comply with the Act, it is subjected to suspension or termination of the privilege to receive federal Medicare funds. ${ }^{253}$ Over ninetyeight percent of the nation's hospitals participate in Medicare. ${ }^{254}$ For many hospitals, terminating the flow of Medicare funds would require them to close their doors. The question arises whether Congress has the constitutional spending power to attach these unrelated conditional provisions to the receipt of federal Medicare funds. ${ }^{255}$

Applying the four criteria set out in Dole ${ }^{256}$ EMTALA surely furthers the general welfare, and it does not violate any independent constitutional provision. EMTALA, however, arguably fails the second and third limitations on the spending power, the requirements that the conditions be unambiguous and related to the purpose for which the funds are spent. ${ }^{257}$ First, many of the definitions in the Act are vague and some of the mandates are beyond a hospital's control. ${ }^{258}$ Second, the condition is not related to the purpose of the funding because only a small number of persons seeking emergency treatment will be Medicare recipients. ${ }^{259}$ In fact, there is little incentive to refuse treatment to a Medicare patient because Medicare offers hospitals an important source of compensation.

Further, EMTALA's constitutionality is suspicious because of its coercive effect. The Supreme Court has historically recognized a difference between conditions attached to spending grants that simply induce and those that coerce, finding coercion violates the spending power. ${ }^{260}$ Just like other spending power limitations, the coercion test is interpreted broadly. The general view is that recipients of federal funds are free to accept the funds

251. 42 U.S.C. $\S 1395$ dd (2005). EMTALA was enacted as part of the Consolidated Omnibus Budget Reconciliation Act of 1986 (COBRA). Id.

252. Id. § $1395 \mathrm{cc}(\mathrm{a})(1)(2005)$.

253. Id. $\S 1395 \mathrm{dd}(\mathrm{d})(1)(2005)$.

254. U.S. Department of Health and Human Services 2005 CMS statistics 80146-23597 Providers and Suppliers, available at http://new.cms.hhs.gov/MedicareMedicaidStatSupp/ downloads/2005_CMS_Statistics.pdf (last visited February 24, 2006).

255. McClurg, supra note 218, 228-33.

256. See discussion supra Part V.B.

257. McClurg, supra note 218, at 230.

258. Id. (arguing that the ability of the hospital to guarantee an ambulance service's actions and know when a patient has been stabilized is ambiguous and may be unobtainable).

259. Id. at 232. A 1986 Cook County study showed only three percent of dumped patients were eligible for Medicare. Id.

260. Steward Mach. Co. v. Davis, 301 U.S. 548, 590 (1937) (recognizing that there may be a "point at which pressure turns into compulsion, and ceases to be inducement ..."). 
with the strings attached or reject them and act without restriction-no coercion is involved. The choice, however, between accepting Medicare funding with EMTALA restrictions attached or losing Medicare funding is hardly a choice at all. ${ }^{261}$ The economic reality is that hospitals depend upon Medicare funding for survival, and this distinguishes Medicare/EMTALA compliance from other spending power cases where the loss of federal funds has a minimal impact upon the recipient. ${ }^{262}$

Despite EMTALA's questionable constitutionality, the history of spending clause litigation does not suggest that hospitals can successfully challenge the Act. ${ }^{263}$ Spending power limitations serve as little more than verbal appeasement and have never been used to strike down a conditional federal expenditure. ${ }^{264}$

To demonstrate just how tenuous a connection the federal government can achieve between Medicare participation conditions and the purpose for which the funds are expended, the United States Department of Health and Human Services lists booting the cars of delinquent parents, denying passports, and prohibiting Medicare participation by health care providers who owe support as Congress' attempt to pursue child support enforcement. ${ }^{265}$ Once again, policing domestic issues is an area traditionally left to the states, and reducing the amount of Medicare providers to accomplish a goal easily achieved by other means is poor public policy.

\section{A National Health Care Plan}

A comprehensive federal health care policy would have to deal with interrelated social, economic, and political issues in order to address the nation's health care needs. ${ }^{266}$ Such a policy would need to achieve many of the following objectives: (1) make health care more accessible; (2) reduce or limit health care costs; (3) provide medical malpractice reform; (4) eliminate duplicate state health care and health-care related programs; and (5) pay for the increased use of health care services. ${ }^{267}$ Comprehensive federal health

261. McClurg, supra note 218, at 232.

262. Id. at 233 (citing Dole, 483 U.S. at 211) (stating that states desiring a lower drinking age would "lose a relatively small percentage of certain federal highway funds," and this loss would not impinge upon a state's ability to continue functioning, so there really is free choice involved).

263. Id.

264. Mizerk, supra note 231 , at 1170 .

265. Ann Laquer Estin, Moving Beyond the Child Support Revolution 26 LAW \& Soc. INQUIRY 505, 525 n.10 (2001) (reviewing Thomas Oldham and Mary S. Melli, eds. Child Support: The New Frontier, 26 LAW \& SOC. INQUIRY 505, 512 n.10 (2001)).

266. James E. Holloway, ERISA, Preemption and Comprehensive Federal Health Care: A Call for "Cooperative Federalism" to Preserve the States' Role in Formulating Health Care Policy, 16 CAMPBELl L. REV. 405, 445 (1994).

267. Id. 
care legislation that establishes a uniform and consistent policy would preempt an abundance of state law. ${ }^{268}$

\section{A. Is the Spending Power Unconstitutional under a National Health Care Plan?}

The spending power has been broadly interpreted; applying the four limitations on spending that the Court has articulated to date, ${ }^{269}$ as well as the coercion test ${ }^{270}$ to a hypothetical situation will help illustrate. Under a comprehensive national health care program (Mega-Care), the funding for the majority of Americans will come from citizens' tax dollars collected by the federal government. If the federal government denies participation based on a provider engaging in activities such as embryonic stem cell research, abortion-related discussions, ${ }^{271}$ physician-assisted suicide or medicinal marijuana recommendations, is this a violation of the spending power of the Constitution? Unlike EMTALA, it certainly is debatable if the exercise of this power would be in the furtherance of the general welfare. So, perhaps Mega-Care violates the first limitation. In addition, the current Court may see this power as a direct assault on federalism. The Rust Court, however, clearly held that "when the Government appropriates public funds to establish a program it is entitled to define the limits of that program."272

The second limitation - that the condition imposed on the recipient must be unambiguous-has been an issue with Medicare participation regulations. ${ }^{273}$ This proviso can easily be overcome, however, by more precise drafting of the Mega-Care Act.

Third, the condition must be related to the federal interest of the national program. This limitation will be tough to violate under Mega-Care. Under the current Medicare program, denying participation to a provider based on activities with non-Medicare patients seems too far removed. Still, EMTALA and Dole demonstrate just how indirect of a relationship will be held to be permissible. The footnote in Dole stated "we do not address whether conditions less directly related to the particular purpose of the expenditure might be outside the bounds of the spending power."274 This leaves the opportunity open to declare future conditional attachments to federal funds unconstitutional. Even so, in the wake of a government monopoly in health care, the relationship will be more direct because the majority of patients will

268. Id. at 445-46 (arguing that a comprehensive health care plan will preempt more state law than ERISA).

269. Dole, 483 U.S. at 207-08.

270. Mizerk, supra note 231, at 1179-1185, 1193-1194.

271. Rust, 500 U.S. at 194.

272. Id.

273. See discussion supra Part V.D.2.

274. Dole, 483 U.S. at 209 n.3. 
be under the federally funded plan. Therefore, almost any condition imposed on participation would be related to some recipient.

The fourth limitation that the conditional grant must not conflict with any independent constitutional provision - would seem at first blush to be a clear violation of the Tenth Amendment grant of " $[t]$ he powers not delegated to the United States by the Constitution, nor prohibited by it to the States, are reserved to the States respectively, or to the people."275 Stated differently, all powers not enumerated to the federal government shall be left to the states or the people. In Printz, the Court found that Congress could not commandeer the states under the Tenth Amendment; however, Justice O'Connor pointed out in her concurring opinion that Congress is free to proceed with the states on a contractual basis. ${ }^{276}$ Therefore in the name of receiving federal funds, very few conditions will be found to induce the states to engage in activities that would themselves be unconstitutional. The coercion test is left, which in the past has been no limitation at all. ${ }^{277}$ Still, it may be premature to concede a challenge to the spending power based on coercion ${ }^{278}$ because a comprehensive program such as Mega-Care may surpass this outer constitutional limit of Congress' power. A strong argument can be made that a monopoly by the federal government in health care leaves providers with no alternative but comply or leave the field.

\section{B. No Limits-No State Laboratories of Democracy}

If the Court does not limit Congress' spending power, the effect will be that legislation passed by the constituents of a state is meaningless in areas that the federal government mandates as invalidating health care participation in Mega-Care. Therefore, experimentation will be discouraged in areas that are not consistent with a national consensus. The result will be that the laboratories of democracy function of states can be regulated out of existence under Mega-Care.

\section{Losing Autonomy for Uniformity}

Even in a less comprehensive system, the fear is that "in providing a minimum standard and some uniformity, [a national health care policy] will have to control health care and health-related interests which are intertwined with numerous fields of state law and public policy ... resulting in the undermining of federalism." ${ }^{.279}$ A comprehensive national health care system

275. U.S. ConsT. amend. X.

276. Printz, 521 U.S. at 936.

277. See discussion supra Part V.B.

278. See McClurg, supra note 218 , at 233 (stating the probability of success in challenging EMTALA's constitutionality is minimal).

279. Litman, supra note 64, at 881 (quoting James Holloway). 
should be approached with caution to prevent uniformity of federal regulatory compliance at the expense of state autonomy in an area as personal as health care. These choices may be reflective of moral choices that are particular to a state electorate or issues that require experimentation before putting the entire nation at risk.

\section{CONCLUSION}

The debate on health care reform is at the forefront of political rhetoric and an issue that must be addressed in the United States. Nationalizing health care, however, is not the solution. A philosophical shift of the Supreme Court toward maintaining state control over traditional state functions is apparent by recent decisions. Specifically, the Court has limited the Commerce Clause, upheld the Eleventh Amendment restriction of judicial power under Article III, and refused to allow the commandeering of the state legislative process by the federal government under the Tenth Amendment. Still, the Court to date has not limited the current scope of the spending power.

A cursory look at the Medicare program demonstrates the power of the federal government when refunding citizens' tax dollars to the States. It can force compliance with mandates which have a tenuous connection with the purpose of the federal program. Many providers must participate in Medicare to remain solvent. Nevertheless, with other options in health insurance and patient selection, the federal program is not a monopoly at this time. A national health care system, however, will create a government monopoly in health care and providers will have the option to take the carrot or starve.

Although an activist Court is not the optimal solution, the spending power must be curtailed for federalism to survive under a national health care system. The exceptional nature of the American system is its bifurcated government created by the Constitution. Under a national health care system that coerces compliance in the name of the spending power, the vital laboratory of democracy function of the fifty states cannot survive. Those areas of health care that require experimentation before nationwide implementation subjects the entire nation to them or those that may never achieve a national consensus because they are unique to an individual state electorate can be regulated out of existence if they do not support federal policy. Gaining uniformity and economies of scale at the cost of accountability and individualism must be analyzed before delving into an untested universal plan in the wake of the current state of Medicare. 